\title{
Design of Measure-control System for a New Type Intelligent Engine Intercooler
}

\author{
Hua Zhou ${ }^{a}$, Xiaojun Jing ${ }^{b}$ and Zenghui Yin ${ }^{c}$ \\ China Automotive Technology and Research Center, Tianjin 300300, China \\ azhouhua@catarc.ac.cn, bjingxiaojun@catarc.ac.cn, cyinzenghui@catarc.ac.cn
}

\begin{abstract}
Keywords: Engine, Intercooler, Measurement technology, Control system
Abstract. In order to improve the engine power and reduce fuel consumption, the supercharger in the engine has been more and more widely used. Intercooler is widely used to obtain a higher in-cylinder charge density. With the introduction of the national sixth stage emission standards, higher requirements for the intercooler was put forward in the heavy engine engine test. Coolant temperature and coolant flow rate of the charge air cooler at the above set point shall not be changed for the whole test cycle. At present, most of the water-cooled intercoolers directly through the control of the cooling water flow or temperature to achieve the cold after the temperature control, these devices have not met the requirements of the test procedures in the national sixth stage emission standards. Therefore, it is important to develop an engine cooling device that meets the requirements of the national $\square$ emission standard test.
\end{abstract}

\section{Introduction}

In order to improve the engine power and reduce fuel consumption, the supercharger in the engine has been more and more widely used. The air temperature of the engine is $300 \mathrm{~K}$ to $330 \mathrm{~K}$ or higher, and the study shows that the temperature of the intake air pressure is reduced by about $10 \mathrm{~K}$ and its density increases by about $3 \%$ and the engine thermal efficiency is increased by about $0.5 \%[1,2]$. In order to obtain a higher in-cylinder charge density, it is necessary to cool the pressurized air. In the vehicle, the pressurized air is cooled with air. On the engine bench test, it is often cooled by the circulating cooling water in the intercooler. Tianjin University, Pan Wang, etc. studied the impact of different intake air temperature on engine performance, he study showed that when the intake air temperature increased, the engine power was reduced and the nitrogen oxide emission was improved [3,4].

With the introduction of the national sixth stage emission standards, higher requirements for the intercooler was put forward in the heavy engine engine test. If a test laboratory system or external blower is used, the coolant flow rate shall be set to achieve a charge air temperature with in $\pm 5 \mathrm{~K}$ of the maximum charge air temperature by the manufacture at the rated speed and full load. Coolant temperature and coolant flow rate of the charge air cooler at the above set point shall not be changed for the whole test cycle, unless this results in unrepresentative over cooling of the charge air. The charge air cooler volume shall be based upon good engineering practice and shall be representative of the production engine's in-use installation. At present, most of the water-cooled intercoolers directly through the control of the cooling water flow or temperature to achieve the cold after the temperature control, these devices have not met the requirements of the test procedures in the national sixth stage emission standards[5,6]. Therefore, it is important to develop an engine cooling device that meets the requirements of the national $\mathrm{VI}$ emission standard test.

\section{Test cycle and the corresponding post-cold temperature}

The temperature after the intercooler is generally considered a target variable for the existing intercooler products on the market. During the test cycle, the temperature after the intercooler is kept constant, which is different from the state's latest test cycle requirements. Therefore, it is necessary to 
carry out experimental research on the post- intercooler temperature of the existing cycle, and provide the theoretical basis for the design of the new intercooler.

Transient Test Cycle WHTC. The transient test cycle WHTC is shown in Figure 1 as a second-by-second sequence of normalized speed and torque values. In order to perform the test on an engine test cell, the normalized values shall be converted to the actual values for the individual engine under test based on the engine-mapping curve. The conversion is referred to as decentralization, and the test cycle so developed as the reference cycle of the engine to be tested. With those references speed and torque values, the cycle shall be run on the test cell, and the actual speed, torque and power values shall be recorded. In order to validate the test run, a regression analysis between reference and actual speed, torque and power values shall be conducted upon completion of the test.

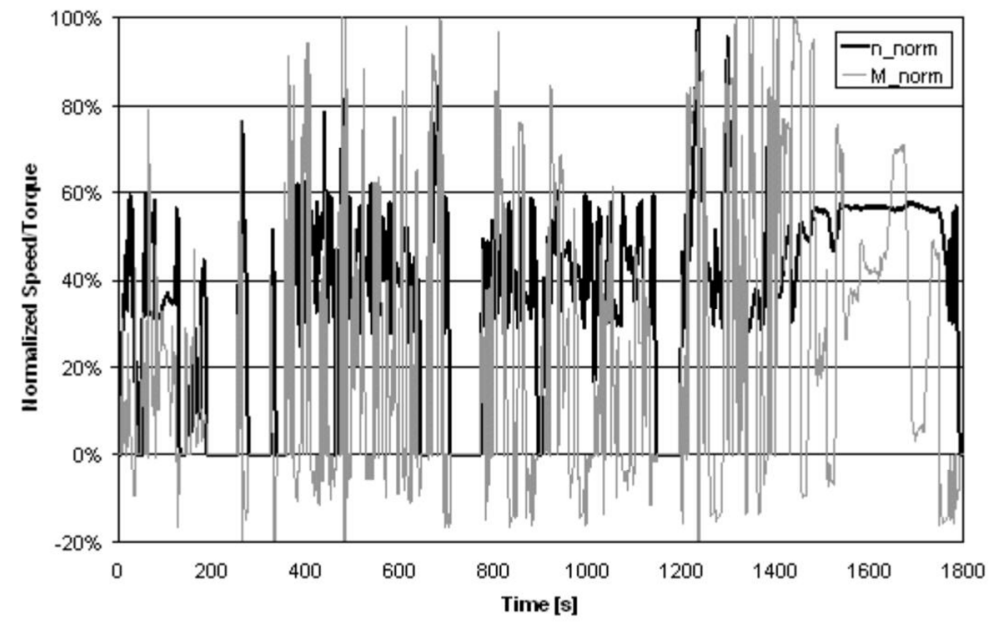

Figure 1. WHTC test cycle

WHTC circle contains cold start test and hot start test. The cold-start test shall be started when the temperatures of the engine's lubricant, coolant, and after-treatment systems are all between 293 and $303 \mathrm{~K}$. Immediately upon completion of the cold start test, the engine shall be conditioned for the hot start test using a $10 \pm 1$ minute hot soak period. The engine shall be started at the end of the hot soak period. As shown in figure 2, the temperature after intercooler does not remain constant, and the WHTC hot is more higher. So a new type intelligent engine intercooler is needed.

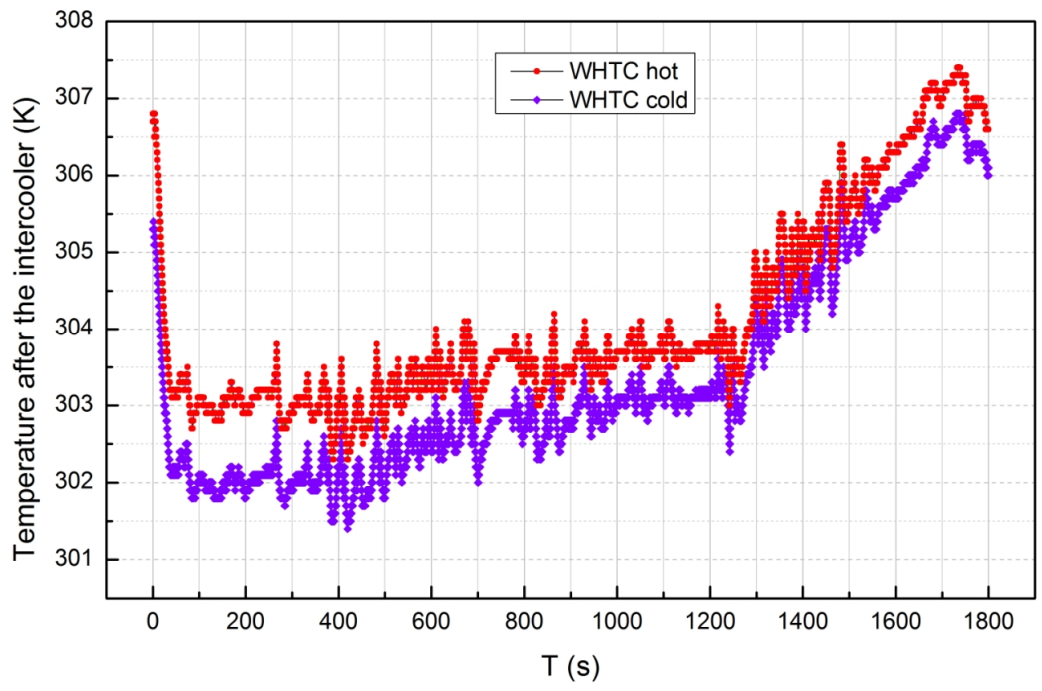

Figure 2. Temerature after intercooler during WHTC test cycle

\section{Design of New Intercooler}

The technical problem to be solved in this study is how to realize the precise control of the temperature before and after the cooler. Coolant temperature and coolant flow rate of the charge air cooler at the 
above set point shall not be changed for the whole test cycle, and the temperature of coolant is more than $20^{\circ} \mathrm{C}$.

In order to solve the above technical problems, this study provides an engine intercooler which meets the requirements of the national VI emission standard test, including: intercooler, tube heater, expansion tank, heat exchanger, variable frequency circulating pump, PLC controller and so on. The intercooler is connected to the engine pressurized gas line and the other side is connected to the engine intake line. The tube heater is connected with the coolant circulation line, which is provided with a safety valve. The expansion tank is installed above the tube heater, and an electronic level sensor is installed in the expansion tank. The expansion tank is equipped with an exhaust valve and an inlet channel. The variable frequency circulating water pump is installed in the intercooler coolant inlet position. PLC controller is used to collect intercooler inlet and outlet side pressure, exhaust side temperature, the temperature of the coolant inlet temperature and other signals. At the same time it is also used to control the opening and closing of the electric butterfly valve, electric ball valve, variable frequency pump speed, tube heater and so on.

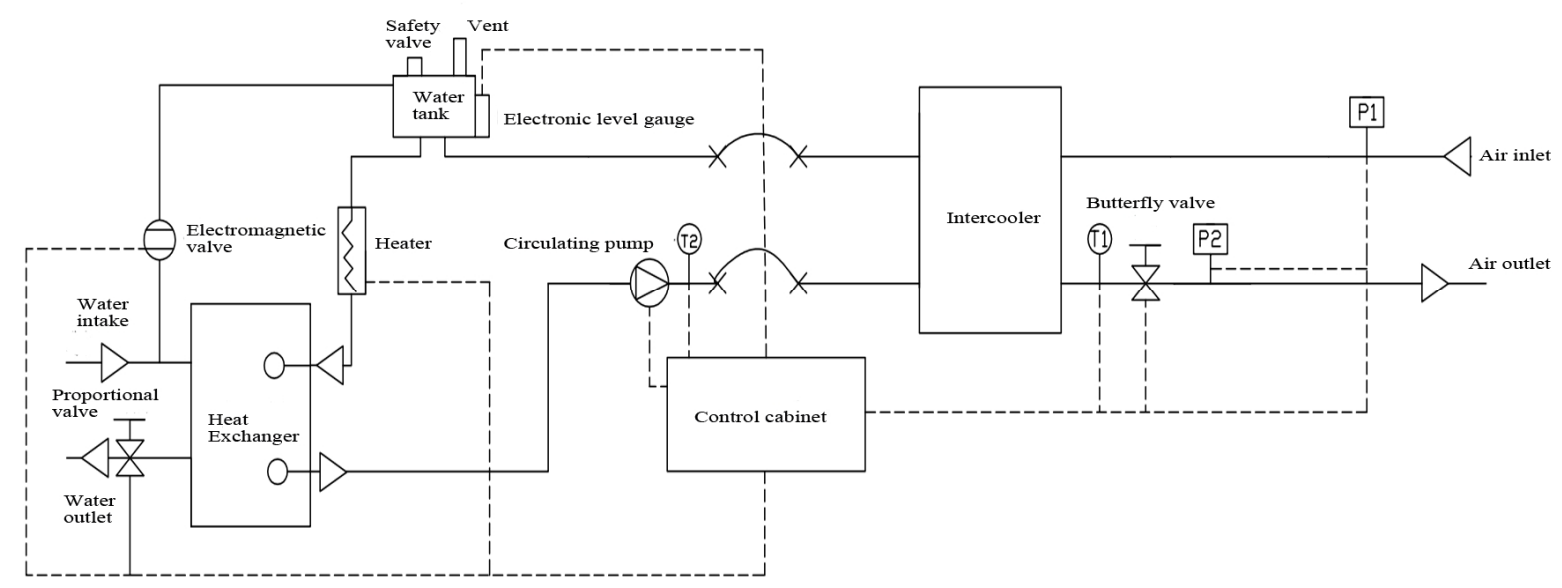

Figure 3. Spray pictures when solenoid opens and closes

In figure 3, the intercooler, which meets the requirements of the national emission standard test, mainly includes intercooler, intercooler inlet pressure sensor, intercooler outlet pressure, temperature sensor, variable frequency circulating water pump, tube heater, expansion tank, Heat exchanger, intercooler water position thermometer, PLC control cabinet, electric proportional valve, electronic level sensor, electric butterfly valve and other components. The test steps and methods are as follows:

Open the control cabinet power supply, the system for liquid level starts the self-test. If the liquid level below the minimum set value, the water injection solenoid valve will be opened, coolant will be supplied automatically. Once it reaches the highest set position, the water injection solenoid valve will be closed.

Set the circulating cooling water target temperature to T2', if the intercooler cooling water inlet position temperature $\mathrm{T} 2<\mathrm{T} 2$, open the tube heater, completely close the chilled water outlet electric proportional valve, when $\mathrm{T} 2=\mathrm{T} 2$ ', the system is ready.

When the equipment is ready, Start the engine to the rated condition. Set the air temperature after intercooler to $\mathrm{T} 1$ ', if the intercooler cooling air out let position temperature $\mathrm{T} 1<\mathrm{T} 1$ ', indicating that the frequency of circulating pump speed too fast, through the PLC controller to reduce the pump speed, making $\mathrm{T} 1=\mathrm{T} 1$ ', and vice versa.

Set the pressure difference between before and after intercooler to $\mathrm{P}^{\prime}$, read the intercooler inlet pressure $\mathrm{P} 1$ and the post-cold pressure $\mathrm{P} 2$, calculate the difference between the two, if $\mathrm{P} 1-\mathrm{P} 2<\mathrm{P}$, reduce the opening of the electric butterfly valve until they are the same.

When the temperature and pressure are stable, open the state fixed button, lock the frequency of the pump and the electric butterfly valve opening position, in the entire test cycle remain unchanged. 
In addition, if the temperature and differential pressure are kept constant in real time in the case of other operating conditions, the state lock function may not be activated to meet other experimental requirements.

\section{Conclusions}

With the above structure, when the coolant coolant temperature is lower than the set temperature, the heat exchanger electronic control proportional valve is closed without heat exchange, the tube heater is opened, when the circulating water temperature reaches the set value, the tube heater Off, you can start the engine test, when the cooling water through the intercooler after the temperature increases, open the proportion of solenoid valve opening, increase the heat exchanger heat transfer, to ensure that the intercooler inlet temperature remains unchanged.

By reading the pipe pressure, adjust the electric proportional butterfly valve to ensure pipe pressure between before and after intercooler unchanged.

When the cold temperature is greater than the target value, increase the frequency of circulating pump speed, increase the circulating flow; when the air temperature is smaller than the set value, reduce the frequency of circulating pump speed, in order to achieve the target value.

When the target temperature and pressure after cooler reach the target values, electric proportional butterfly valve and circulating pump speed are fixed to ensure that the coolant circulation flow remains unchanged. If you want to ensure that different operating conditions, the target temperature and pressure to remain unchanged, do not manually open the state lock, to achieve a diversified control mode intelligently.

\section{References}

[1] Park Y, Bae C. Experimental Study on the Effects of High/low Pressure EGR Proportion in a Passenger Car Diesel Engine. Applied Energy, Vol.133(2014), P.308.

[2] Liu M X, Liu X L and Wu D Y. Research on Numerical Simulation and Experiment of Plate Fin Type Intercooler in Turbocharged Natural Gas Engine.Applied Mechanics and Materials. Vol.628(2014),P.275.

[3] Seljak T, Oprešnik S R and Katrašnik T. Combustion characteristics of tire pyrolysis oil in turbo charged compression ignition engine. Fuel, Vol.150(2015), P.226.

[4] Yang Y J, Sim H S. A Study on Simulation of an Water Cooling Intercooler for a Small Marine Diesel Engine. Journal of the Korean Society of Manufacturing Process Engineers, Vol.13(2014) , P.43.

[5] Camilleri W, Anselmi E, Sethi V, et al. Performance Characteristics and Optimisation of a Geared Intercooled Reversed Flow Core Engine. Proceedings of the Institution of Mechanical Engineers, Part G: Journal of Aerospace Engineering, Vol.229(2015), P.269.

[6] Eichler D I F, Kahrstedt DIJ, Pott I E, et al. The New Three-Cylinder Engine from Volkswagen's Modular Diesel Engine System. MTZ worldwide, Vol.75(2017) , P.18. 